\title{
SUBJECTS OF PUBLICATIONS IN THE FIELD OF POLITICAL GEOGRAPHY IN UKRAINE DURING 1990-2012 YEARS
}

\author{
Valentyn STAFIICHUK \\ Taras Shevchenko National University of Kyiv, Ukraine \\ valikosta@ukr.net
}

\begin{abstract}
Since 1990, the Ukrainian political geography is passing through the latest stage of its development: the number of political and geographical publications were significantly increased and their content was expanded. Based on scientometric analysis of the main geographical magazines of Ukraine during 1900-2012 years 368 articles with political and geographical content were found. The topics of publications in the field of political geography is rather broad and relatively balanced. Almost $50 \%$ of articles are devoted to the history of political geography, political geography of Ukraine, electoral geography, the theory and methodology of political geography and political geography of individual regions. The widest range of topics are covered in the "Journal of the Lviv University. Geographical Series" and the scientific book "Geography and Tourism".
\end{abstract}

Key words: political geography, publication in the field of political geography, special edition, subjects of articles

UDC: $911.3: 32$

\section{ТЕМАТИКА ПОЛІТИКО-ГЕОГРАФІЧНИХ ПУБЛІКАЦІЙ В УКРАЇНІ ЗА 1990-2012 РОКИ}

\author{
Валентин СТАФІЙЧУК \\ Київський національний університет імені Тараса Шевченка, Україна \\ valikosta@ukr.net
}

\begin{abstract}
Анотація: 31990 року українська політична географія переживає новітній етап свого розвитку: значно збільшилася чисельність і розширився зміст політико-географічних публікацій. На основі проведеного наукометричного аналізу провідних географічних часописів України за 1900-2012 роки було виявлено 368 статтей політико-географічного змісту. Тематика політико-географічних публікацій є досить широкою і відносно збалансованою. Майже 50\% статтей присвячені історії політичної географії, політичній географії України, електоральній географії, теорії і методології політичної географії та політичній географії окремих регіонів. Найбільш широкий спектр тем висвітлено у «Віснику Львівського університету. Серія географічна» та науковому збірнику «Географія та туризм».
\end{abstract}

Ключові слова: політична географія, політико-географічна публікація, фахове видання, тематика публікацій

УдК: 911.3:32

Вступ. Постановка проблеми. Українська державність нині переживає складний етап становлення, однак причини подій, що відбуваються довкола Криму та на сході України, важко назвати одномоментними. Вони накопичувалися протягом всього періоду незалежності нашої держави. У всі попередні періоди саме відсутність адекватного аналізу ситуації як політиками, так і науковцями, їх «сліпа» віра в окремі ідеології або «зовнішню підтримку» призводили до чергової колонізації i поділу українських земель. У даній статті спробуємо виявити, наскільки сучасні українські політикогеографи адекватно оцінювали суспільно-політичну ситуацію та перебіг подій в державі і чи були вони, принаймні, в наукових колах, носіями ідеї творення європейської, а не євразійської, України.

За період 1990-2012 років в Україні з'явилася низка навчальних посібників i монографій та захищено десятки дисертацій політикогеографічного змісту (наприклад, Дністрянський М. [3; 4; 5], Яценко Б. [1], Трохимчук С., Федунь О. [8], Яценко Б., Стафійчук В., Брайчевський Ю. та ін. [2]; Дністрянський М., Голод А., Кузик П., Лотоцький С., Малиновська О., Миронюк В., Тітенко 3., Хан С. тощо).

(C) В. Стафійчук
У своїй більшості ці праці носили узагальнюючий та академічний характер і в жодній з них не було мови про функціональну структуру політико-географічних публікацій на сучасному етапі розвитку української політичної географії.

Динамічність політичних процесів має більш широкий відгук та актуальне висвітлення не в монографіях чи підручниках, а в наукових статтях. Саме на аналізі тематики статтей сконцентруємо нашу увагу. Аналіз територіальної структури авторства політико-географічних публікацій за вказаний період був поданий нами у збірнику «Географія та туризм» [6].

Аналіз останніх досліджень і публікацій. Для наукометричного аналізу нами були відібрані всі фахові географічні видання, рекомендовані Державною атестаційною комісією МОНУ [7], та найвпливовіші географічні часописи, що не потрапили до цього списку. Загалом, за період 1990-2012 рр. було виявлено 368 статтей політикогеографічного змісту у 14 часописах (відсутні публікації у часописах «Культура народів Причорномор'я» та «Проблеми безперервної географічної освіти і картографія»). Розподіл статтей по окремих виданнях подано на рис. 1.

Формулювання цілей статті. Постановка 


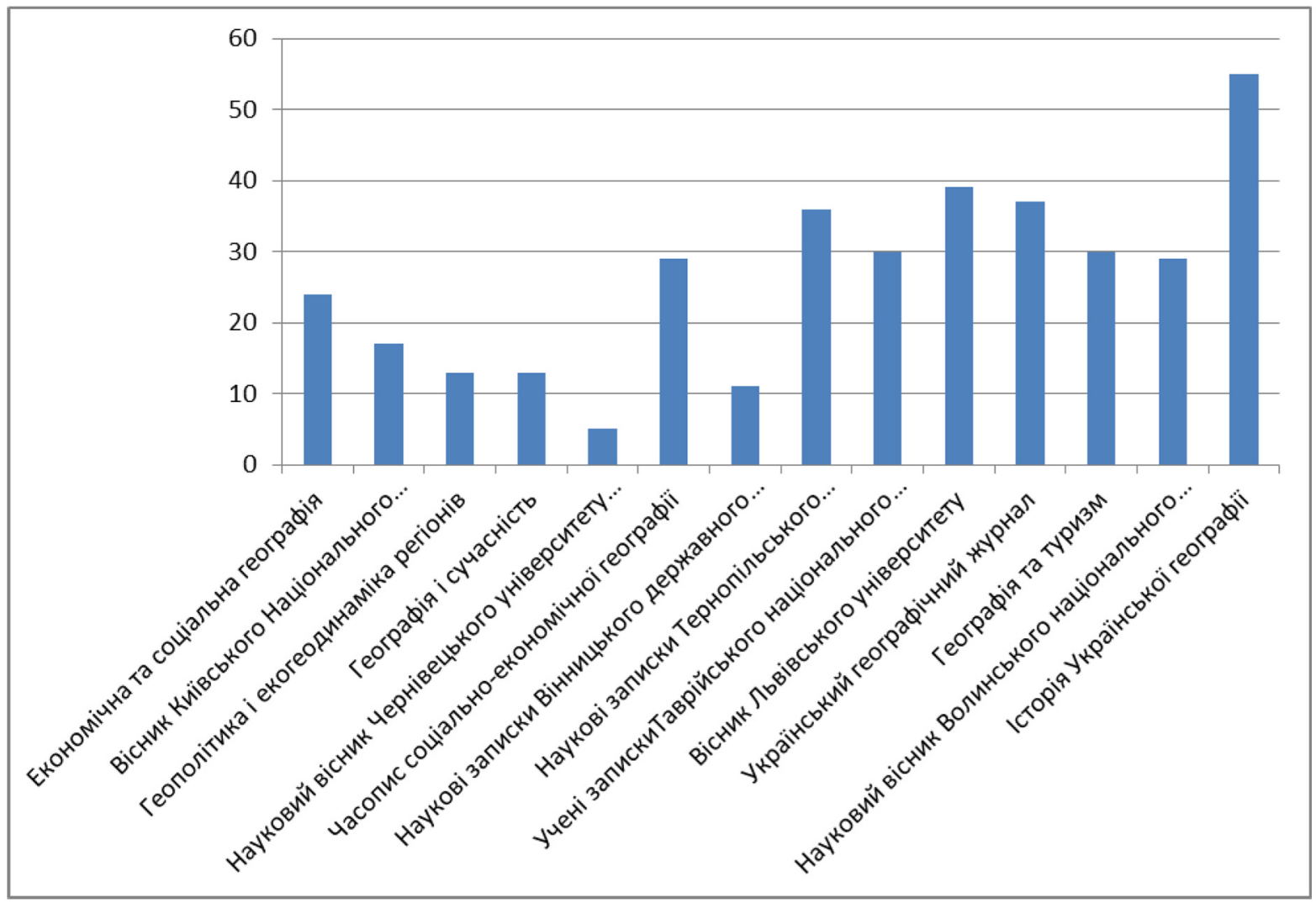

Рис. 1. Чисельність політико-географічних публікацій в українських географічних часописах у 1990-2012рр.

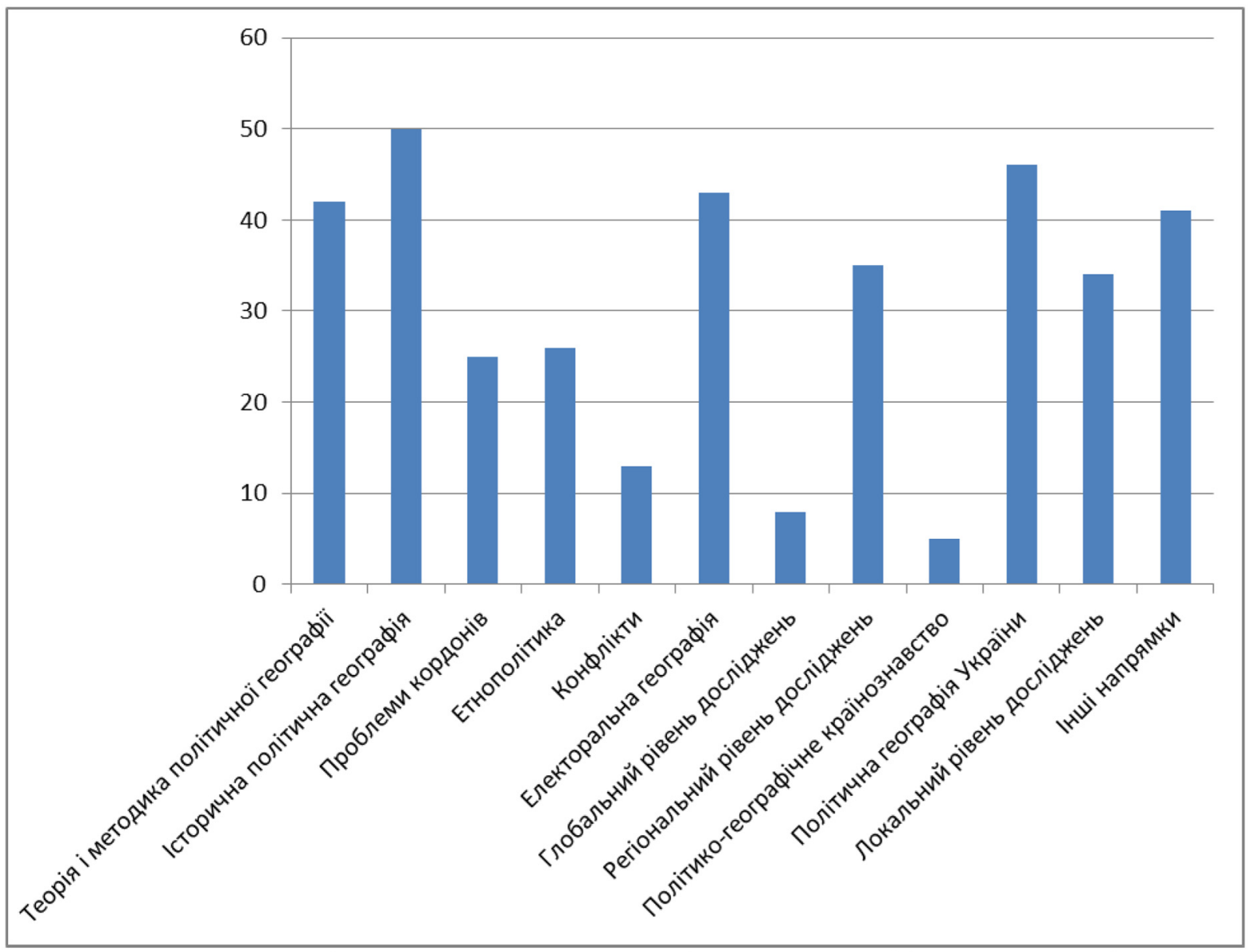

Рис. 2. Розподіл за темами політико-географічних публікацій в українських географічних часописах у 1990-2012 pp. 
завдання. Головне завдання даної праці - виявлення тематики статтей політико-географічного змісту, які були опубліковані у фахових виданнях України за період 1990-2012 років. Аналіз політикогеографічних публікацій у наукових часописах був ускладнений тим, що в багатьох 3 них відсутня вимога щодо наявності УДК, а заявлена анотація не відповідає реальному змістові статті. Тому підставою для віднесення публікації до політико-географічної проблематики повністю або частково нами було обрано їі зміст.

Виклад основного матеріалу. Для зручності аналізу всі політико-географічні публікації відносно теми були зараховані до однієї з 12 груп. Назви груп відповідають структурі політичної географії та основним напрямкам політико-географічних досліджень на сучасному етапі. Тематичні блоки та кількість публікацій у кожному 3 них за проаналізований період подано на рис.2.

Статті усіх 12 напрямків присутні у «Віснику Львівського університету. Серія географічна». Це видання стало першим, де після тривалого бездержавного існування в Україні знову з'явилися політико-географічні розвідки. Так була започаткована одна 3 перших новітніх шкіл політичної географії часів незалежності. Майже кожна 5-а стаття (18\%) політико-географічного змісту була присвячена теоретичним і прикладним проблемам електоральної географії [див. рис. 3]. Приблизно половина статтей (43\%) віднесені нами до різних рівнів регіональної політичної географії (політико-географічні проблеми України, Галичини, Криму, Чернівецької та Закарпатської обл., Мармарощини, Центральної Європи тощо). Цікавлять авторів також етнополітичні процеси та мовна політика на загальноукраїнському i регіональному рівнях. Окремі статті присвяченні теоретико-методологічним проблемам (методологічні та методичні підходи до оцінки адміністративнотериторіального устрою i дослідження політикогеографічних процесів у прикордонних районах, поняття транскордонної географії, групування європейських країн за розмірами території) та внеску О. Степанів і В. Кубійовича у розвиток української, в т.ч. політичної, географії. Авторами опублікованих статтей були Вісьтяк О., Влах Р., Гальчак А., Гонак М., Дністрянський М., Дубович I., Жулканич Б., Зінько І., Книш М., Коваль С., Куреляк В., Лабінська Г., Лозинський Р., Миронюк В., Ровенчак I., Склярська О., Сливка Р., Смоляніков С., Уманців Б.

Лише з 2009 р. кафедра країнознавства і туризму Київського національного університету імені Тараса Шевченка видає науковий збірних «Географія та туризм», однак за різноманітністю тематики статтей політико-географічного змісту він вже серед лідерів. В регіональному розрізі найчастіше об'єктом дослідження виступають інтеграційні угрупування або історико-географічні регіони (17\%; Південна Америка, Антарктида, регіон Чорного, Червоного та Середземного морів, Центральна Свропа, Шанхайська Організація Співробітництва) та Україна загалом

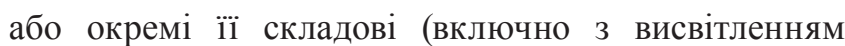
проблем функціональної політичної географії на прикладі України). Автори зосереджують увагу на окремих аспектах прикордонних та міжнародних конфліктів (10\%), висвітлюють політико-географічні проблеми етнополітики (10\%), глобалізації, кордонів. Окремі праці присвяченні політико-географічним питанням функціонування світосистеми, столичних міст, методиці обрахунку політичної глобалізації, транснаціональній злочинності, адміністративнотериторіальному поділу Японії, аналізу теорії цивілізацій А. Тойнбі тощо. Авторство статтей належить широкому колу політико- та суспільних географів (Винниченко I., Брайчевський Ю., Ворфлік Г., Дирда А., Дорошко М, Дякова Є., Клименко С., Коваль К., Котик Л., Книш М., Кравченко Т., Лисак К., Медовар Б, Ніщименко В., Олійник С., Просвірніна С., Римаренко М., Сидорук В., Сливка Л., Сливка Р., Смирнов I., Стафійчук В., Стащук Ю., Федчук А., Чичкань А., Яценко Б.).

Редакційна колегія наукового збірника «Економічна та соціальна географія» також досить часто публікує статті політико-географічного змісту. Їх тематика майже пропорційно акцентує увагу на проблемах кордонів (17\%), електоральної географії (17\%), теорії та методиці політичної географії (13\%) і прикладних аспектах політичної географії України (13\%). Геополітичні вектори України, роль етнополітичних факторів у сучасних світових процесах, столичний статус Києва, політикогеографічний вплив конфлікту в Придністров’і - ці та інші політико-географічні проблеми теж знайшли відображення у публікаціях даного збірника, серед авторів якого: Гладкий О., Глибовець В., Джаман М., Дністрянський М., Доценко А., Дубовіч I., Дудник I., Іщук С.,Кавецький I., Клочко Р., Копачинська Г., Малиновська О., Мезенцев К., Мезенцева Н., Олещенко В., Олійник Я., Пістун М., Сологуб Ю., Стафійчук В., Степаненко А., Черевко О., Шишацький В., Шуканов П. та ін.

Статті різноманітної політико-географічної тематики присутні в «Українському географічному журналі». Відносна більшість статтей (27\%) присвячена актуальним проблемам політичної географії України (геополітичне положення, адміністративно-територіальний поділ, державні кордони, етнонаціональні відносини, глобальні виклики) та їі регіонів (Закарпаття, Крим). Особливо слід відмітити статті по теорії та методології політичної географії (24\%). В трійку лідерів за кількістью публікацій ввійшла історична політична географія (11\%). Варто також зазначити, що окремі iз відзначених нами статтей висвітлюють теми 3 економічної та соціальної географії, картографії, географії населення або ж транспорту, однак їх магістральною ідеєю є політико-географічна проблематика. Відносно збалансовано представлені глобальний, регіональний та локальний рівні дослідження. У часописі відсутні публікації, де б 3 політико-географічної точки зору розглядалися теоретичні проблеми кордонів та конфлікти. В 


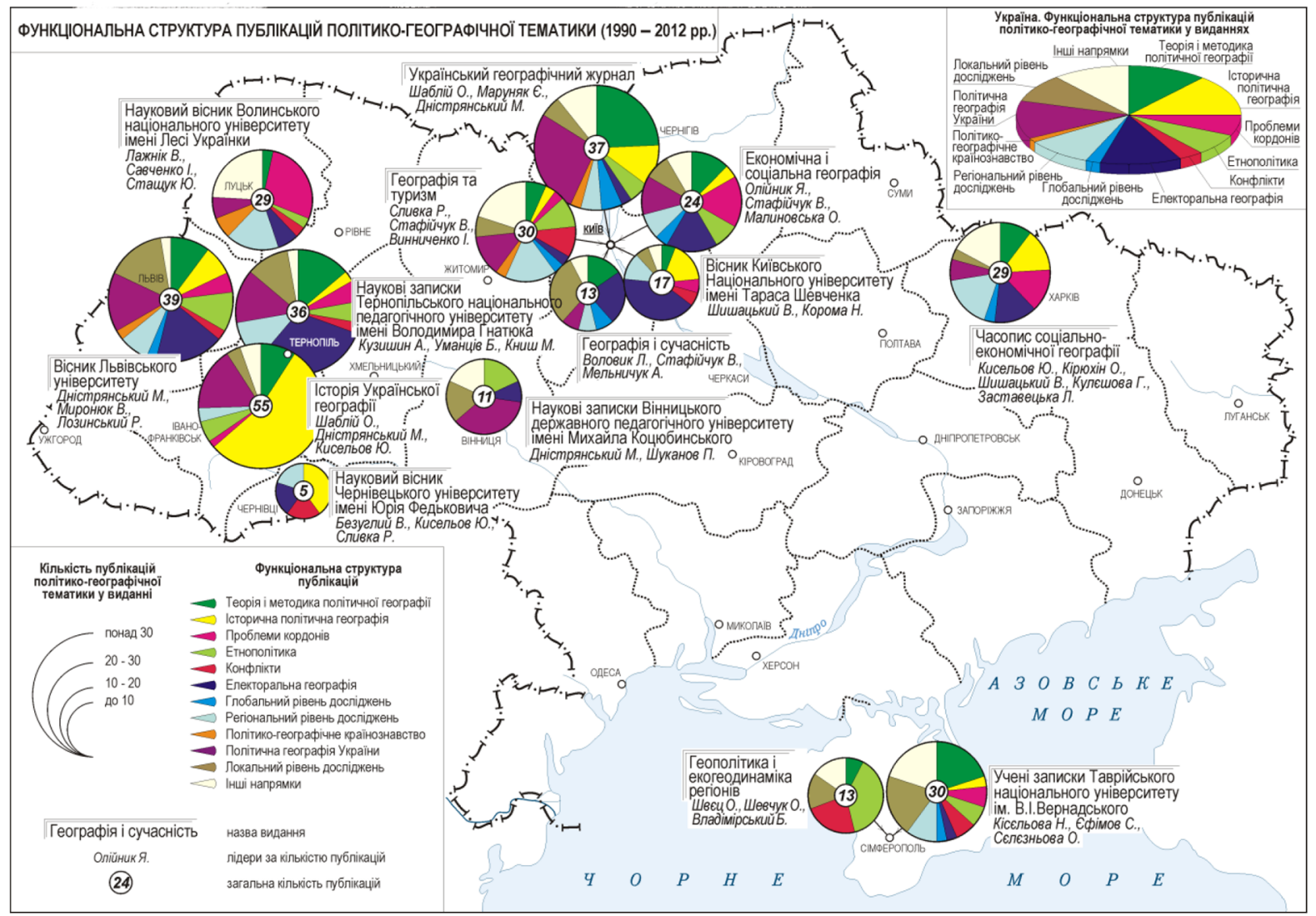

Рис. 3. Тематика політико-географічних публікацій у фахових географічних виданнях України за 1990-2012 роки.

«Українському географічному журналі» опублікували результати своїх політико-географічних досліджень Багров М., Барбаш Ю., Бондар А., Буряк О., Денисенко О., Дністрянський М., Свтух В., Зінич В., Лукшин I., Луцишин П., Ляшенко Д., Маруняк Є., Наулко В., Нікітіна М., Паламарчук М., Паламарчук Л., Паламарчук О., Руденко Л., Савчук I., Cocca P., Стафійчук В., Стебельський В., Топчієв О., Трюхан М., Хан Є., Шабашова Л., Шаблій О., Яценко Б.

Часопис «Наукові записки Тернопільського національного педагогічного університету імені Володимира Гнатюка. Серія: Географія» 31998 p. теж долучився до видань, що публікують статті політико-географічної проблематики. Їх тематика досить широка, однак серед лідерів статті 3 електоральної географії, в т.ч. України (31\%), політичної географії України (14\%) та теорії i методики політичної географії (14\%). Окремі статті присвячені регіональному та локальному рівням; питанням, пов'язаним 3 етнополітикою, функціонуванням кордонів i прикордонних територій, територіальними суперечками, спадком Гериновича В. тощо. Дописувачами часопису 3 політико-географічної тематики були Влах М., Гладковський Р., Геренчук М., Голод А., Греков С., Грицевич В., Данилишин Р, Дарчук К., Дітчук I., Дністрянський М., Заставецька О., Заставецький Т., Івах Я., Кавецький I., Калько А., Книш М., Костащук I., Костриця М., Кузишин А., Лозинський Р., Лукащук Л., Мрінська О., Пістун М., Поручинський В., Прицюк Н.,
Склярська О., Стащук Ю., Торушанко В., Уманців Б. «Учені записки Таврійського національного університету ім.В.І.Вернадського» - один 3 найстаріших наукових журналів України, оскільки виходить з 1918 року. У 2001 році він збагатився географічною серією. Особливо слід відмітити публікації з теорії і методики політичної географії (20\%; використання ГІС технологій для забезпечення місцевого самоврядування, електронного урядування та реформи адміністративно-територіального устрою; кількісна оцінка прикордонного положення територій; поняття «прикордонного простору» та «територіальноелекторальної системи» тощо) та ті, що розкривають прикладні політико-географічні проблеми регіонального рівня (20\%), особливо стосовно Криму. Окремі автори висвітлюють теоретичні аспекти функціонування кордонів, сецессіонізму, проблеми бікамералізму, етнополітики, політико-географічних аспектів розмежування Арктики та Антарктики тощо. У збірнику не виявлено жодної статті, що була б присвячена прикладним питанням політичної географії в цілому України або будь-якої іншої держави. Багров М., Безверхнюк Т., Безуглий В., Бирладін О., Городецький С., Дністрянська Н., Дністрянський М., Єфімов С., Заставецька Л., Карпенко С., Кісєльов А., Кісєльов С., Кісєльова Н., Лажнік В., Латушко А., Лисенко Г., Мельничук А., Нестеренко О., Нетреба А., Ожегова Л., Приходченко Л., Сєлєзньова О., Стащук Ю., Ткач І., Швєц О., Шевчук А., Яковлєв А. були дописувачами наукового збірника за проаналізований період. 
32006 p. у Харкові виходить «Часопис соціально-економічної географії». За цей короткий період у ньому опубліковано понад два десятки статей політико-географічного змісту, значною мірою аспірантів, магістрів та студентів. Періодично у збірнику висвітлюються політико-географічні проблеми регіонального рівня (17\%;), електоральної географії (14\%;), кордонів та прикордонних територій (14\%), теорії і методики політичної географії (10\%). «Часопис...» №3 за2007 р. присвячений 130-му ювілею С.Рудницького. Присутні в збірнику і результати політико-географічних досліджень України, світу, територіальних політичних систем локального рівня тощо. Авторами публікацій у «Часописі...» були Безуглий В., Вісьтяк О., Грицевич В., Дубович I., Дячевська Л., Задворний С., Заставецька Л., Кисельов Ю., Кірюхін О., Кулєшова Г., Логвин М., Нємєц Л., Полякова К., Смирнов І., Тітенко 3., Топчієв О., Шаблій О., Шишацький В., Шуканов П.

«Науковий вісник Волинського національного університету імені Лесі Українки. Серія: Географічні науки» - це єдиний в Україні збірник наукових праць, де є розділ «Соціальна і політична географія» (до 2012 р. - «Політична та історична географія»). Значна кількість публікацій $є$ результатами студентських наукових розвідок. Теми публікацій у даному збірнику піднімають різноманітні політико-географічні проблеми, однак особливий акцент зроблено на висвітленні проблем кордонів, прикордонних територій та транскордонного співробітництва (28\%). Окремі статті присвяченні важливим питанням регіональної взаємодії в басейні Чорного моря, Закавказзя, Центральної Європи, Європейського Союзу (17\%). Зустрічаються праці 3 електоральної географії (в т.ч. на основі даних по Волинській i Рівненській областях), політико-географічного країнознавства (Австрія, США, Бельгія, Туреччина тощо), політичної географії України тощо. Серед географів, що були дописувачами вісника Артьоменко С., Андросюк Н., Бойко О., Дністрянська Н., Дністрянський М., Калько А., Карпчук Н., Кисельов Ю., Копачинська Г., Корнійчук А., Корольова Л., Корома Н., Корчун В., Коцан Н., Лажнік В, Мандрик I., Моренчук А., Мишляєв Т., Наход М., Новак I., Пиза С., Савченко I., Сасюк А., Слива Л., Стащук Ю., Черней Е.

Цілком логічно, що всеукраїнський науковотеоретичний часопис «Історія Української географії» робить акцент на висвітленні історії розвитку української політичної географії і внеску в іii становлення окремих вчених (55\%) та на політико-географічних проблемах України (16\%). Редакційна колегія окремі номери присвячуе видатним українським географам (С. Рудницький, В. Кубійович) та здійснює передрук знакових праць минулих років. Зокрема були надруковані праці політико-географічного змісту С. Рудницького, В. Кубійовича, О. Степанів, В. Гериновича. Крім того, часопис висвітлює питання теорії та методології політичної географії, етнополітики; політикогеографічну ситуацію в окремих регіонах світу; проблеми кордонів України, окремих iï складових тощо. Відсутні статті, які присвячені електоральній географії, політичним конфліктам, глобальному рівню та окремим зарубіжним державам. У збірнику за проаналізований період опублікували свої праці Вісьтак О., Влах М., Грицевич В., Гуцал В., Дітчук I., Дністрянський М., Доценко А., Дубович I., Дубчева А., Заставецька О., Кавецький І., Кандиба Ю., Кисельов Ю., Костриця М., Круль В, Лозинський Р., Мариняк Я., Менделюк А., Олійник Я., Пістун М., Ровенчак I., Рудакевич О., Руденко В., Сенейко О., Склярська О., Тітенко 3., Топчієв О, Трохимчук С., Уманців Б., Хомра I., Чернюх О., Шаблій О., Штойко П.

«Вісник Київського Національного університету імені Тараса Шевченка. Географія» - авторитетне та багатопрофільне наукове географічне видання. $41 \%$ опублікованих у ньому праць політикогеографічного змісту висвітлюють проблеми електоральної географії. Популярними напрямками наукових розвідок також $\epsilon$ історія розвитку політичної географії (17\%) та визначення місця і ролі України в Балто-Чорноморському регіоні (12\%). Одиничні статті присвячені іншим проблемам політичної географії (україно-польський кордон, адміністративно територіальна реформа в Україні, периферійність адміністративної одиниці, геоконфліктологія). У «Віснику...» були опубліковані праці Винниченка І., Ворфлік Г., Іщука С., Короми Н., Малиновської О., Матвієнка В., Олійника Я., Пилипенко І., Подольського А., Хомри І., Шаблія О., Шишацького В.

«Науковий часопис Національного педагогічного університету імені М.П.Драгоманова. Серія 4. Географія та сучасність» періодично теж публікує статті політико-географічного змісту. Найчастіше у часописі піднімаються питання прикладних політико-географічних досліджень локального рівня (31\%), електоральної географії (23\%) та теорії і методики політичної географії (15\%). Приблизно половина із зазначених на рис. 2 тем у часописі не висвітлювалися. Свої статті у 1990-2012 роках тут опублікували Бабарицька В., Влах М., Воловик Л., Гладковський Р., Гнатюк О., Голод А., Книш М., Мельничук А., Подольський А., Савченко I., Стафійчук В., Шишацький В.

Час від часу статті політико-географічного змісту з'являються у «Наукових записках Вінницького державного педагогічного університету імені Михайла Коцюбинського». Лідером у розрізі тематики є проблеми політичної географії України (37\%), локального рівня, етнополітики, електоральної географії. Загалом, 83 11опублікованих статтей присвячені політикогеографічним проблемам України та їі регіонів: адміністративно-територіальний устрій, етно-мовна ситуація, електоральні вподобання виборців тощо. Свій науковий доробок в часописі представили Воловик В., Гладкий О., Джаман В., Джаман М., Дністрянський М., Дудник I., Іщук С., Любченко В., Тітенко 3., Троценко О., Шишацький В., Шуканов П.

Дещо обмеженою $є$ тематика наукового журналу «Геополітика і екогеодинаміка регіонів». Особливу 
увагу тут приділяли політико-географічній суті етнополітики в АР Крим (39\%) та проблемам сецессіонізму i конфліктам (23\%). Цікавими $\epsilon$ дослідження ефекту космічної погоди в терористичній активності; сучасних політико-географічних факторів еволюції системи розселення в Криму; етнолінгвістичної рубіжності Кіровоградської області. Політико-географічну тематику на сторінках журналу висвітлювали Владімірскій Б., Грігор'єв П., Кісєльов С., Кісєльова Н., Лисенко А., Мартинюк В., Маслова Н., Назілов Р., Ожегова Л., Швєц О., Шевчук О., Шумскій В., Яковлєв А.

«Науковий вісник Чернівецького університету імені Юрія Федьковича» за проаналізований період опублікував 5 статтей політико-географічного змісту, 2 з яких присвячені історії розвитку політичної географії. Піднімалися в ньому також проблеми електоральної географії, конфліктології та регіонального рівня. Результати своїх досліджень тут опублікували Безуглий В., Геренчук М., Греков С., Кисельов Ю., Кузишин А., Сливка Р.

Стосовно широти політико-географічної проблематики всі проаналізовані часописи можна об'єднати в три групи:

- часописи, де присутні політико-географічні публікації, що зачіпають практично весь спектр досліджень сучасної політичної географії (не менше 10 тематичних напрямків) - «Вісник Львівського університету. Серія географічна», «Географія та туризм», «Економічна та соціальна географія», «Український географічний журнал», «Наукові записки Тернопільського національного педагогічного університету імені Володимира Гнатюка. Серія: Географія», «Учені записки Таврійського національного університету ім.В.І.Вернадського»;

$$
\text { часописи } 3 \text { відносно різноманітною }
$$
тематикою політико-географічних публікації (6-9 тем) та акцентами на окремих темах - «Науковий вісник Волинського національного університету імені Лесі Українки. Серія: Географічні науки», «Часопис соціально-економічної географії», «Історія Української географії», «Вісник Київського Національного університету імені Тараса Шевченка. Географія», «Науковий часопис Національного педагогічного університету імені М.П. Драгоманова. Серія 4. Географія та сучасність»;

- часописи 3 невеликою кількістю та відносно вузьким спектром статтей політико-географічного змісту (4-5 тем) - «Наукові записки Вінницького державного педагогічного університету імені

Михайла Коцюбинського», «Геополітика і екогеодинаміка регіонів», «Науковий вісник Чернівецького університету імені Юрія Федьковича».

Висновки і перспективи подалыших розвідок. Серед українських політико- та суспільних географів найбільш популярними напрямками політикогеографічних досліджень у 1990-2012 роках були:

- історія політичної географії (внесок окремих вчених у становлення i розвиток української політичної географії; етапи становлення світової та української політичної географії) - 14 \% від усіх статтей політико-географічного змісту;

- політична географія України (політикогеографічне положення, державні кордони та етнічні межі, політико-адміністративний устрій, етно-мовна ситуація тощо) - $12 \%$;

- електоральна географія (чинники електоральних вподобань українців, аналіз результатів виборів, політико-географічне районування України, географія виборів в окремих державах світу) - 12\%;

- теорія i методика політичної географії (формування понятійно-термінологічного апарату, обгрунтування предметної суті науки, аналіз методів дослідження, розробка критеріїв оцінювання) - 11\%;

- регіональна політична географія (висвітлення політико-географічних проблем Свропейського Союзу, постсоціалістичного простору, Північноамериканської зони вільної торгівлі, БалтоЧорноморського простору, НАТО тощо) - $10 \%$.

Ще один висновок, що напрошується, це широкий спектр і відносна збалансованість тем, що висвітлюються українськими географами.

У вітчизняній політичній географії, виходячи 3 особливостей розвитку України, певна кількість публікацій присвячена політико-географічним проблемам формування української нації, ролі України у світових та регіональних політичних процесах і явищах, участі у міжнародних об'єднаннях та вирішенні глобальних проблем людства.

На глобальному та локальному рівнях проводяться дослідження місця і ролі у політичних процесах міжнародних організацій, інтеграційних угруповань, військових блоків, транснаціональних компаній, місцевих органів влади, націй, релігій, анклавів та ексклавів, столиць, світових міст, терористичних груп, об'єднань, що виступають проти політичної, расової, релігійної, гендерної або сексуальної дискримінації.

На жаль, можна констатувати той факт, що українські географи недостатньо або взагалі не приділяли уваги обгрунтуванню євроінтеграційної стратегії України, дослідженню політикогеографічної складової україно-російських стосунків, виявленню політико-географічних наслідків багатовікової російської колонізації України (геноцид українців, русифікація, релігійна експансія, насадження комплексу меншовартості, зміна ментальності тощо) та шляхів їх подолання, розвінчуванню російських міфів про спільну «колиску», історію та єдність українського і російського народів.

У контексті російської окупації Криму та частини української території на Донбасі цим проблемам варто приділити особливу увагу. Імперська Росія ніколи не була i ніколи не буде дружньою до незалежної України державою, оскільки вже саме існування непідконтрольної Москві України несе загрозу існування міфів, на яких вона себе вибудувала. Українські політико-географи, як і історики та політологи, мають всі можливості і нагальну потребу у розвінчуванні російських «міфів», принаймні, серед українців. Цей процес не $є$ приниженням росіян, це - процес відновлення історичної правди, 
який у далекій перспективі допоможе і росіянам у формуванні не імперського мислення. Українські політико-географи можуть і повинні, в тому числі посередництвом статтей, робити все, що допоможе українцям і українській владі адекватно оцінювати сучасну ситуацію і реагувати на виклики.

\section{References:}

1. Âcenko B.P. Politična geografiâ: navčal'nij posibnik [Political Geography: Textbook]. Kyiv, 2005, 134 p. (In Ukrainian).

2. Âcenko B. P., Stafijččk V. I., Brajčevs'kij U. S. et al. Politična geografiâ ì geopolitika [Political Geography and Geopolitics: Textbook]. Kyiv, 2007, 255 p. (In Ukrainian).

3. Dnìstrâns'kij M. S. Politična geografiâ ta geopolitika Ukraïni [Political Geography and Geopolitics of Ukraine]. Ternopil', 2010, 344 p. (In Ukrainian).

4. Dnìstrâns'kij M. S. Politična geografiâ Ukraïni [Political Geography of Ukraine]. L’viv, 1997. (In Ukrainian).

5. Dnìstrâns'kij M. S. Ukraïna v politiko-geografičnomu vimìrì [Ukraine in terms of political geography]. L'viv, 2000, 310 p. (In Ukrainian).

6. Stafijčuk V. Teritorìal'na struktura avtorstva politiko-geografičnih publikkacij v Ukraïnì za 1990-2012 roki [Territorial structure of the authorship of publications in the field of political geography in Ukraine during 1990-2012 years]. Geografiâ ta turizm [Geografiâ ta turizm], 2014, Vol. 27, pp. 184-191 (In Ukrainian).

7. The new general list of professional publications printed [electronic resource] - access mode: http://aspirantura. org.ua/nauchniy jurnal_text/u_noviy-obshiy-perechen-pechatnih-professionalnih-izdaniy_2.html (In Ukrainian).

8. Trohimčuk S. V., Fedun' O. V. Politična geografîa svitu: navčal'nij posibnik [Political geography of the world: Textbook]. Kyiv, 2007, 422 p. (In Ukrainian). 